\title{
Megalakult a Gazsó Ferenc Társadalomtudományı Társaság (GFTT)
}

\author{
$\underline{\text { DOI } 10.35402 / \text { kek.2019.1.14 }}$
}

Gazsó Ferenc tisztelői és barátai kezdeményezésére 2018. december 12.-én megalakult az egyesületi formában működő Gazsó Ferenc Társadalomtudományi Társaság, amelynek célja a névadó szellemi örökségének gondozása. Ennek keretében olyan közéleti ügyeket, kutatási kérdéseket igyekszünk napirenden tartani, amelyek

a közoktatás társadalmi összefüggéseire és az oktatáspolitikára,

a magyar társadalom generációs újratermelỏdésének alakulására és az ifjúságkutatásra,

az életesélyek társadalmi egyenlőtlenségeire vonatkoznak.

A fenti megfontolások szem előtt tartásával a Társaság a következő közvetlen célokat tűzi ki maga elé:

Konferencia-sorozatot szervez, amelyben elöadások hangzanak el és eszmecserék szerveződnek Gazsó Ferenc emlékének szentelt és a Társaság által fontosnak tartott fenti témákban.

Gazsó Ferenc Emlékdijjat alapít, amelyet egy erre a célra választott kuratórium - kétévente - ítél oda két fiatal magyar kutatónak, akik a fenti témák valamelyikében komoly, rangos kutatómunkát végeznek.

Az iskolaügy, az ifjúság, valamint a társadalmi egyenlőtlenségek témaköreiben szervezett konferenciák előadásait kötetekben tervezzük közreadni. Előkészületben van a 2019-ben - „Iskola, társadalom, politika" címmel - megjelenő kötet, amely Gazsó Ferenc e témakörben korábban publikált, illetve eddig még nem közölt írásait, valamint más szerzőknek a témához kapcsolódó tanulmányait adja közre.
A Társaság abban a szellemben müködik, amelyet Gazsó Ferenc fontosnak tartott: minél kevésbé formális, lényegre törő, egyszerű működésre, baráti, empatikus légkörre, nyitott szellemi közeg megteremtésére törekszik. Értékelkötelezett szakszerűség és a társadalmi problémák iránti nyitottság jellemzi a Társaság múködését, amelyet elvár az általa támogatott személyektől is. Az alakuló Közgyülés Dr. Bihari Mihályt választotta a Társaság elnökévé.

A Társaság nyitott. Tagjává válhat mindenki, aki a fentiekben megfogalmazott célokkal, értékekkel és eszközökkel egyetért, elfogadja a Társaság alapszabályát, és írásban közli az Elnökséggel belépési szándékát (tagfelvételi kérelem), továbbá, akinek felvételét a Társaság két alapító tagja írásban támogatja. A Társaság körébe várjuk mindazokat, akiket a Társaság céljai és szakmai programja érdekel, és közreműködésükkel segíteni kívánják azok megvalósítását. A Társaságot a tagok adományaira alapozva kívánjuk mủködtetni. Az érdeklődők további információt kaphatnak Békés Zoltántól (bekes. zoltan@chello.hu) és Harcsa Istvántól (istvan.harcsa@yahoo.com).

\section{A Gazsó Ferenc Társadalomtudományi} Társaság Elnöksége 


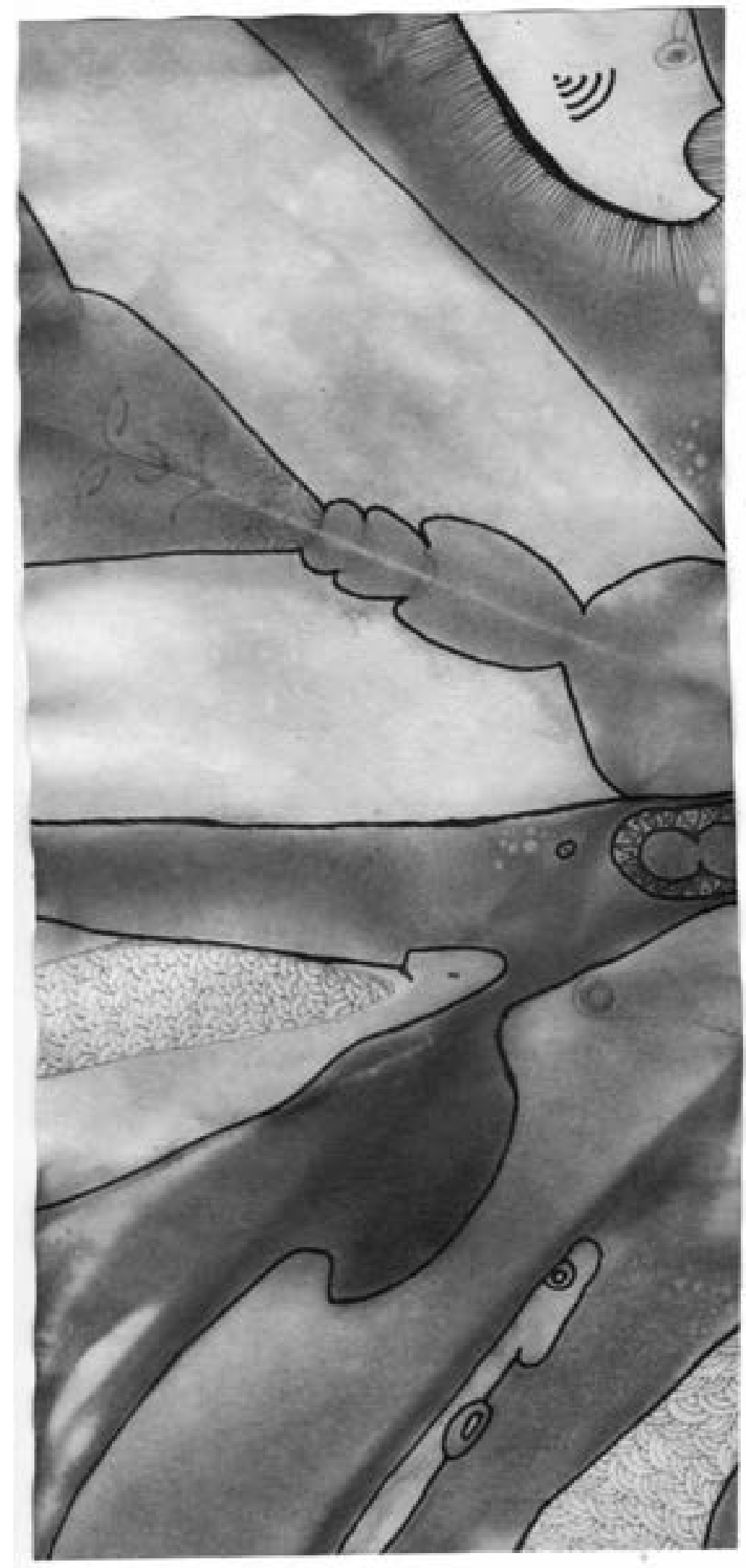

Handó Péter-Ó és jaj (szinfogó kendö, alkoholos filc, 11,5×24,5cm) 


\section{JAVASLAT \\ a Gazsó Ferenc Társadalomtudományi Társaság (GFTT) \\ 20 19-202I KÖZÖTtI SZAKMAI MUNKAPROGRAMJÁRA}

A Gazsó Ferenc szellemi örökségének formális keretek közötti ápolására létrehozott Társadalomtudományi Társaságot a Gazsó Ferenc által művelt témakörökben elért tudományos eredmények további gazdagítása érdekében hozzuk létre. Az itt megfogalmazott javaslatok meghatározzák az egyesületi formában működő Társaság profilját. Célszerűnek látszik rövidebb, illetve hosszabb távra szóló célokat kitűzni. Utóbbiak megvalósítását az első évek erőfeszítéseinek kedvező szakmai és társadalmi fogadtatására támaszkodva érhetjük el. A Munkaprogram módosítható, illetve kiegészíthető a továbbiakban.

\section{Rövid távú célok}

I. Szakmai konferenciák a Gazsó Ferenc által müvelt témakörökben, illetve az erre az alkalomra készitett írások kötetekben való kiadása.

Több nagyobb témakör jön szóba, az oktatási rendszer, az ifjúságkutatás, a társadalmi egyenlötlenségi rendszer, valamint a politikai tagolódás és politikai szocializáció.

Ami az oktatási rendszer témakörét illeti, Gazsó Ferenccel közösen elkezdtük az iskolaüggyel kapcsolatos kötet szerkesztését, ennek munkálatai folytathatók az Ö elhunyta után is. A kötet szerkesztése és a szövegek gondozása folyamatban van. A kötet feltehetően 2019 első felében jelenhet meg, a Belvedere Kiadó gondozásában. Kézenfekvönek tünhet, hogy a kötetbemutatót szakmai konferenciával kössük össze, amelyre - hozzászólóként - a téma néhány szakértöjét kérhetnénk fel.

2020 első felében az ifjuság helyzetének komplex bemutatására törekvő konferenciát lehetne rendezni. Ez - követve a Gazsó Ferenc vezetése alatt szervezett ifjúságkutatási gyakorlatot és szemléletet -, annyiban térne el az utóbbi 10-15 évben szervezett ifjúsági tematikájú rendezvényektől, hogy nem egyetlen adatfelvételre, illetve az abban lefedett tematikai körre szorítkozna, hanem részben más adatforrásokra is támaszkodna, részben olyan témaköröket is magába foglalna, amelyre az ifúsági nagymintás vizsgálatok és más korábbi felvételek nem fókuszáltak. Egy ilyen típusú rendezvény elő- készítése sok munkát, és akár célzott kutatásokat is igényelhet, amelyek finanszírozásához pályázati forrásokra van szükség. Lehetséges azonban, hogy első lépésben csak a Gazsó Ferenc vezetése alatt zajlott kutatások szemléletének „visszahozására” nyílik lehetőség, és a komplexebb megközelítés realizálását csak egy hosszabb távú kutatási koncepció keretében lehet megvalósítani. A kutatás kivitelezésében számítunk az egykori kutatótársakra.

Megfontolandó, hogy 2021 elején a politikai tagolódással és politikai szocializációval kapcsolatos témakör kerüljön műhelykonferenciára, amely mögött az szólhat, hogy Gazsó Ferenc - a korábban megjelent kötet kapcsán - úgy érezte: annak ezzel kapcsolatos fejezete szerényebbre sikeredett, mint ahogy azt a téma fontossága indokolta. Hosszabb beszélgetéseket terveztünk Stumpf Istvánnal és Boros Lászlóval, annak érdekében, hogy ez a témakör bővebb értelmezést kapjon. Egyébként pedig úgy vélem, hogy a jelenlegi társadalmi-politikai szituációban aktualitása is lehet a témakörnek. Az erről készített konferenciakötet 2021 őszén jelenhetne meg.

II. A Gazsó Ferenc által vezetett korábbi ifjúságkutatási munkák dokumentálása értékmentö jelleggel, illetve azok kritikai értékelése.

A fenti cím alatti kutatás a 2020 elejére tervezett ifúsági témájú konferencia megalapozását célozná. E témakörben Békés Zoltán elkezdte az előzetes tájékozódást, Harcsa István pedig egy alapvetően módszertani jellegű előadásra készül, továbbá számítunk Szabó Andrea közreműködésére is. A kutatás előzetes tervét a melléklet tartalmazza. A kutatáshoz költségvetést kell rendelni.

\section{Egyéb szakmai rendezvények}

A szülöváros jellemzöi, társadalomtörténeti metszetben. Az „elsö termék” a 2019 öszére tervezett, ünnepélyes alakuló ülés alkalmával kerülne bemutatásra. A feltáró jellegű kutatást Laki László végezné. Harcsa István és Laki László azt tervezi, hogy - tájékozódás céljából - felkeresi a helyi önkormányzatot, és megpróbál az iskolák vezetésével is kapcsolatot teremteni. 
Tervezzük egy Gazsó Ferenc tiszteletére készüló emlékkötet összeállitását, és ezzel kapcsolatosan egy emlékkonferencia megrendezését. Ennek időzítését a fenti programok figyelembe vételével kellene kialakítani.

IV. Gazsó Ferenc munkásságához kapcsolódó dokumentumok gondozása.

Egy ilyen jellegű dokumentum már elkészült, nevezetesen „Szociológiai szótár, Gazsó Ferenc: Pályakép a szociológia sodrásában címü kötetéhez", amelyet Szabó Iván állitott össze. A szerző ezt azzal a kéréssel adta át a számunkra, hogy próbáljuk meg valahogy hasznosítani, pl. oly módon, hogy a kötet második kiadása esetén ahhoz mellékletként csatoljuk. Egyébként Laki Lászlót kérte meg az anyag átnézésére.

V. Ismeretek összegyüjtése azon „tápláló gyökerekröl”, amelyek Gazsó Ferenc kutatói habitusának alakulásához hozzájárultak (az általa használt tájnyelv, népi mondások, stb.).

$\mathrm{Az}$ ötletet Bihari Mihály vetette fel, aki Gazsó Ferenccel való hosszú barátsága során számos olyan nyelvi fordulatot, népi bölcseletet, mondásokat hallott tőle, amelyek számos adalékot nyújthatnak ahhoz, hogy megérthessük a közéletben és a kutatásokban megfigyelhető „egyenes tartását”, és általában a társadalmi kérdésekhez való viszonyát.

VI. Gazsó Ferenc szellemi hatása szülövárosának iskoláira, társadalomtörténeti metszetben. A „kétpillérü" müködés lehetséges formái.

Az előbbi pontban a szülőföld kultúrájának Gazsó Ferencre gyakorolt hatását vettük célba, itt viszont fordítva, arra lennénk kíváncsiak, hogy volt-e lokális kisugárzása Gazsó Ferencnek? Itt nem elsősorban az ismertsége az érdekes, hanem az, hogy az általa elvetett „magokból” mi csirázott ki helyben? Ez esetben Békésszentandrás iskoláiban meghonosodó szellemiséget, valamint a dokumentumokból is kiolvasható szakmai, adminisztratív és politikai gyakorlatot lehetne górcső alá venni, társadalomtörténeti metszetben. A szellemiséget, a kisugárzást leginkább az idősebb pedagógusokkal való, oral history jellegü beszélgetések tárhatnák fel. Így például érdekes lenne megtudni, hogy miként gondoltak Gazsó Ferencnek az iskola működésével kapcsolatos elképzelésire, amikor a mindenkori politikai kurzusok által diktált módszereket kellett alkalmazniuk? Egyáltalán, mércét jelentettek-e szá- mukra Gazsó által megfogalmazott módszerek és szellemisége?

A kutatást - a jövőt illetően - bizonyos értelemben pilotnak is lehet tekinteni, hiszen az alapvető problémafelvetések szintjén azokat a szakmai standardokat követné, amelyeket Gazsó Ferenc és Laki László korábbi iskola-kutatásaiban megfogalmazódtak. Elsö lépésben el kell késziteni a kutatási tervet, amelyhez költségvetést kell rendelni.

Egyébként Gazsó Ferenccel közösen terveztük, hogy az iskolaügy kapcsán elutazunk szülővárosába helyi tapasztalatokat szerezni. Halála miatt ezt az elképzelést Laki Lászlóval valósítanánk meg.

Itt jegyezzük meg, hogy a felvetett tematika egyúttal jó alapot nyújtana a Társaság „két-pilléren” nyugvó működéséhez, nevezetesen ahhoz, hogy a fóvárosi központ mellett Békésszentandráson is megszerveződhessenek a szellemi örökség ápolásának feltételei.

VII. Gazsó Ferenc további nem publikált irásainak áttekintése.

Ez alapján át kell gondolni, hogy azokból mit célszerủ közölni. (Gazsó L. Ferenc javaslata.) Harcsa István ez ügyben elkezdte az előzetes tájékozódást. Gazsó Ferenc szellemi hagyatékáról pedig leltárt készítünk, amelyet bárki elérhet.

\section{A Társaság honlapjának létrehozása.}

A honlap - a tevékenységet illetően - részben egyfajta tükör lehet nemcsak a tagok, hanem a külvilág felé is, részben ellátja a dokumentációs „tárház" szerepét is.

\section{Hosszabb távú célok}

A GFTT tevékenységének sikeres fogadtatása esetén az alábbi hosszabb távú célok fogalmazhatók meg:

\section{Kutatások kezdeményezése a Gazsó Ferenc által müvelt témakörökben}

Itt elsősorban olyan jellegű kutatások jönnek szóba, amelyek az ifjúság helyzete, oktatásügy, valamint politikai tagozódás stb. témakörökben áttekintést adnak az adott terület főbb kérdésköreiről, és egyúttal kritikai értékelést adnak ezekről. Mindezt egyfajta mérlegkészítés és összegzés jegyében lehetne elvégezni, a tanulságok levonásával, és kizárólag az előzetesen kiválasztott részterületekre vonatkozóan, hiszen mindegyik terület nagyon szerteágazó. Az 
egy-egy nagyobb témakörön belüli, kiemelt kérdésköröket bizonyos rendezőelvek alapján választanánk ki. Minden témakörben néhány fós „csapatok” alakítanák ki a kutatási programok részleteit.

Pályadíjak, elsősorban olyan fiatal kutatók számára, akik a Gazsó Ferenc által múvelt témakörökben alkotnak. Ennek részleteit az e célra létrehozott zsűri dolgozná ki.

\section{Szakmai programok koordinálása}

A különböző szakmai programokat megvalósító munkacsoportok segítésére, a szakmai munka koordinálására egy több-kevesebb folyamatossággal működő Szakmai munkacsoportot hozunk létre, amely ellátja a szakmai programok előkészítését, koordinálását, beleértve a rendezvények megszervezését, valamint a konferenciakötetek összeállítását. A munkacsoport működtetné a Társaság honlapját is. A munkacsoport magja már kialakult, tagjai az „Iskola, társadalom, politika” címmel jelenleg szerkesztés alatt levő köteten dolgozók, nevezetesen Békés Zoltán, Harcsa István, és Szabó Andrea. A munkacsoport nyitott, amelyhez várjuk más kollégák csatlakozását.

\section{A programok múködtetésével kapcsolatos} kérdések

A programok egy része nem igényel anyagi forrásokat, hiszen az eddigi gyakorlathoz hasonlóan bizonyos feladatokat a szellemi örökséget ápoló kollégák elvégeznek, a rendezvények céljára szükséges termeket pedig a BCE, vagy más oktató és kutatóhelyek díjtalanul a rendelkezésünkre bocsáthatják. Az ezen felüli feladatok ellátására viszont pályázati forrásokra, illetve adományokra lesz szükség.

Készitette: Harcsa István 